\title{
Hard Palate Lesion due to Herpes Zoster Virus Infection
}

\author{
Tomoka Gomibuchi ${ }^{1,2}$ and Takahiko Tsutsumi ${ }^{1,3}$
}

Key words: herpes zoster virus infection, trigeminal nerve, acyclovir

(Intern Med 55: 2747, 2016)

(DOI: 10.2169/internalmedicine.55.7064)

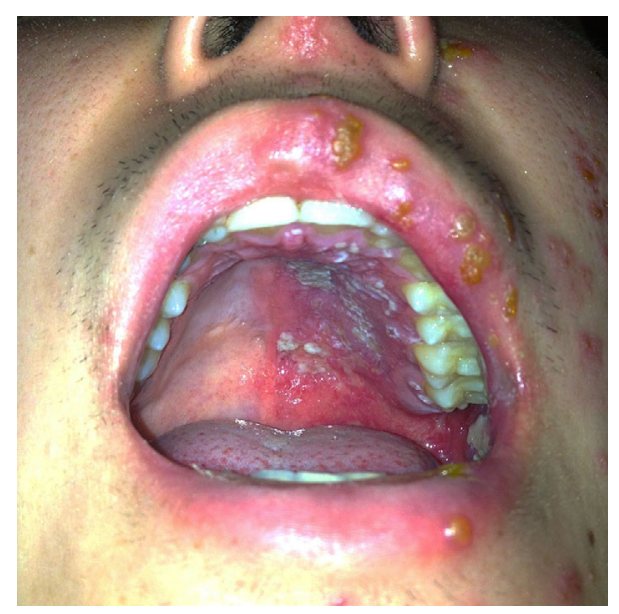

Picture.

A 22-year-old Japanese man presented with a sore throat, headache and a low-grade fever followed by an erythematous rash with vesicles. The rash was unilateral and involved the left side of his face and hard palate (Picture), suggesting a disseminated herpes zoster virus (HZV) infection of all three divisions of the trigeminal nerve (1). Lumbar puncture revealed pleocytosis with a negative culture, which suggested aseptic meningitis. Further history taking confirmed a primary HZV infection at four years of age.

The patient's past history was relevant for total colectomy secondary to ulcerative colitis three years prior to this presentation. Although immunosuppressive agents had not been used for many years, there was a possibility that the immune response to HZV was impaired in this patient (2). All assays to detect immunosuppression, including HIV testing, were negative.

The patient was started on a 10-day course of intravenous acyclovir. He responded well to the treatment and was later discharged with no residual symptoms.

The authors state that they have no Conflict of Interest (COI).

\section{References}

1. Cohen JI. Herpes zoster. N Engl J Med 369: 255-263, 2013.

2. Marin AC, Gisbert JP, Chaparro M. Immunogenicity and mechanisms impairing the response to vaccines in inflammatory bowel disease. World J Gastroenterol 21: 11273-11281, 2015.

The Internal Medicine is an Open Access article distributed under the Creative Commons Attribution-NonCommercial-NoDerivatives 4.0 International License. To view the details of this license, please visit (https://creativecommons.org/licenses/ by-nc-nd/4.0/).

\footnotetext{
${ }^{1}$ Department of General Internal Medicine, Nerima Hikarigaoka Hospital, Japan, ${ }^{2}$ The School of Public Health, The University of Tokyo, Japan and ${ }^{3}$ Department of General Internal Medicine, Akashi Medical Center, Japan

Received for publication January 4, 2016; Accepted for publication January 12, 2016

Correspondence to Dr. Takahiko Tsutsumi, tutuhiko0405@yahoo.co.jp

(C) 2016 The Japanese Society of Internal Medicine Journal Website: http://www.naika.or.jp/imonline/index.html
} 